\title{
Population dynamics of two spotted spider mite, Tetranychus urticae Koch on French bean (Phaseolus vulgaris L.)
}

\section{RINKI KUMARI CHAUHAN* AND ABHISHEK SHUKLA}

Department of Entomology, N.M. College of Agriculture, Navsari Agricultural University, NAVSARI (GUJARAT) INDIA

\section{ARITCLE INFO}

Received : 28.06 .2016

Revised : 02.09.2016

Accepted : 16.09 .2016

KEY WORDS :

Population dynamics, Two spotted spider mite, Tetranychus urticae Koch, French bean

*Corresponding author: Email : crinky246@gmail.com

\begin{abstract}
Studies on population dynamics of $T$. urticae on French bean cv. GUJARAT RAJMAH revealed that the two spotted red spider mite remained active throughout the crop season in open field condition. The incidence of T. urticae was started from the $1 \mathrm{st}$ SMW (first week of January), increased gradually and reached to its peak during 21 st SMW (mid of May) (14.27 mite/leaf) in the open field condition. The maximum, minimum, average temperature, evening and average relative humidity had significantly positive correlated with mite population, while morning relative humidity had nonsignificant correlation with $T$. urticae population.
\end{abstract}

How to view point the article : Chauhan, Rinki Kumari and Shukla, Abhishek (2016). Population dynamics of two spotted spider mite, Tetranychus urticae Koch on French bean (Phaseolus vulgaris L.). Internat. J. Plant Protec., 9(2) : 536-539, DOI : 10.15740/HAS/IJPP/9.2/536-539. 